\title{
MEN BEHAVING BADLY: CONDUCT AND IDENTITY AT GREEK SYMPOSIA
}

\author{
WJ Henderson (Rand Afrikaans University)
}

\section{Introduction}

From later prose writings on the ancient Greek symposion (for example, Plato's Symposion, Xenophon's Symposion and Athenaeus' Deipnosophistai) one gains the general impression that the symposion was a gathering of aristocrats with similar interests, who, induced by moderate consumption of wine, indulged in intellectual discussions and pursuits and exercised their reputed sophrosyne. ${ }^{1}$ This is, however, a literary construct, an ideal, which is undercut by the evidence of the poetry sung and pottery used at these functions. Both the sympotic poetry and the painted pottery offer evidence from inside the symposion of less than ideal behaviour. The mere fact that the vase-painters or their aristocratic clients felt it necessary to warn symposiasts against over-indulgence (cf. for example, the "message" of the Brygos-calyx), suggests that the behaviour after (or even at) symposia was perhaps not always as moderate as one might at first be led to believe. The evidence is particularly damning in the case of komasts after the symposion (cf. Lissarrague 1990:96, fig. 77). Likewise, the poets' appeals for calm and self-control, promotion of the moderate consumption of wine, and warnings against its dangers presuppose situations where in fact these elements were absent.

In the wider context of everyday reality there were also less ideal examples of sympotic gatherings. Here one recalls the excessive behaviour of Hippocleides at the banquet given by Cleisthenes for his daughter's betrothal (Hdt. 6.129). His wineinduced display of dancing on the table cost him the tyrant's daughter in marriage (cf. Robertson 1991:26-29). ${ }^{3}$ Fisher (1989:26-29) noted, in post-5th century texts, the praise for Spartan control over drunkenness and hybris in comparison with the situation in Athens. Plato (Minos 320) actually claims that of all Greeks, only the Cretans and Spartans abstained from symposia and drunkenness (cf. Fisher 1989:44 n.10). The Spartans were also, again according to Plato (Leg. 637A-639E), against "deep drinking" ( $\left.\mu \varepsilon^{\prime} \theta \eta\right)$ and the public display of drunkenness and its consequences: hubris, excessive (mostly sexual) behaviour, brawling, vandalism, assaults, and seditious acts. The Spartan syssitia were, according to this construct, quite different from the Athenian symposia, the latter being characterised by over-indulgence,

1 Plato does, however, also hold negative views of the symposion; cf. Tecusan 1990 and Slater 1991b:2-3.

2 For an illustration, cf. Arias 1962: photo 138, plate XXXIII. There are other examples in Durand, Frontisi-Ducroux \& Lissarrague 1989:126, fig. 170; and Maas \& Snyder 1989:86, 115, 132 fig. 8. Cf. Henderson 1997:7 and "Aspects of the ancient Greek symposion", Akroterion 45 (2000) (forthcoming).

3 For further examples of dissolute behaviour, see Booth 1991:105-17; Paul 1991:159-62. 
various versions, groups of similar ages (usually young, irresponsible and loutish), free and open discussions, and clash of ideas (Fisher 1989:32-38). Murray (1991:8794) has called this distinction between the Spartan (and Cretan) syssitia (for the promotion of courage) and the Athenian symposion (for the indulgence of pleasure) a "false opposition", arising from "laconism" in the 4th century. Yet, even if we allow for this pro-Spartan/anti-Athenian sentiment, it does seem clear that symposia, at Athens, and from the 5 th century, were not always disciplined, sober and intellectual occasions.

This is confirmed by Bowie in an article on the structural function of the symposion in Aristophanes' comedies. Bad behaviour, and improper and disordered habits at table and during the kômos recur and are measured against "an idealised sympotic practice of balance and restraint, which obviously was not reflected in all actual symposia" (Bowie 1997:4).

There are, therefore, sufficient indications to question the general belief, found in ancient and modern writings alike, that the Greek symposion was always characterised by moderate and disciplined behaviour. It was often enough the occasion for less acceptable conduct that elicited admonitions addressed to the symposiasts. These admonitions were often reinforced by examples of the unacceptable behaviour of "others". ${ }^{4}$

The theme of the 1997 conference of the Classical Association of South Africa was "Multiculturalism in Antiquity". In his Chairperson's Address on the state of Classics in South Africa, Richard Whitaker alluded to the phenomenon of "essentialising", a process of type-casting, by which those outside one's own social, political, cultural or ethnic circle are defined and labelled in highly selective, reductionist terms. ${ }^{6}$ This phenomenon of categorising people into "We" and "They" is not unknown in the Greek world. ${ }^{7}$ Lissarrague $(1990: 11-14,58-59)$ has argued that in ancient Greek society the symposion provided the stimulus and opportunity to experience the Other, a different nature or mode of behaviour. In this exclusive, "safe" milieu, old men could act like youths, men could dress like women or Scythians, and the behaviour of non-human beings (such as satyrs) and ethnic types (such as Blacks and Asians) could be portrayed if not actually imitated. As another example of the Greek sense of exclusivity, he quotes Thales' three reasons for his gratitude to the gods (ap. Diog. Laert. 1.33): 1. because he was a human being and not an animal; 2 . because he was a man and not a woman; and 3 . because he was a Greek and not of another race. Lissarrague (1990:59) even regards this "serial exclusion" as typically Greek (which it was not). Whether this interpretation of the vase-iconography is correct or not, ${ }^{8}$ one can, in the surviving texts of Greek melic

4 Roman writers, in their turn, attacked the excesses of "Greeks"; cf. Sall. BC 11.4-7; Juv. 13.3346; and Booth 1991:105.

5 Cf. AClass 1994:97-117 for summaries of the papers presented.

6 Whitaker 1997:9.

7 Cf. the summaries of the papers of Callinicos and Hift in AClass 1994:97, 103.

8 Cf. Miller 1991:59-71, who rejects the oriental cap (kidaris) as an index of the presence of Scythians at Attic symposia and in the Athenian army (61-66), or as a symbol of oriental 
poetry, distinguish three types of "characterisation by group" or "essentialising": (1) Greeks vs non-Greeks; (2) one Greek state vs another; and (3) one private group vs another. Murray (1991:84) justifiably calls this "stereotype of otherness" a "fictional construct". This article examines the relevant lyric texts in order to highlight this facet of the Greek symposion.

\title{
1. Greeks vs non-Greeks
}

The earliest surviving text on the behaviour of the Scythians is by Anacreon. For him their drinking was characterised by rowdiness and noise, and he exhorted his fellowsymposiasts to act differently: by implication to be quieter, and, explicitly, to drink more slowly.

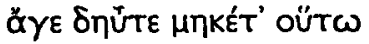

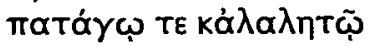

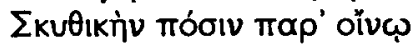

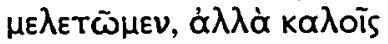 \\ úTOTÍVOVTES Év ÜHVOIS. \\ Come again, let us no more \\ with racket and wailing \\ practise Scythian drinking \\ over our wine, but drink slowly \\ amid beautiful praise-songs.
}

Anacreon, $P M G$ fr. $356 \mathrm{~b}^{9}$

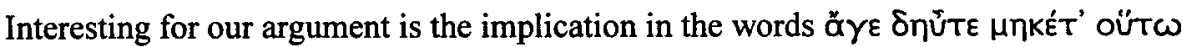
that, in fact, the Greek symposiasts were behaving rather like Scythians to elicit the poet's admonition. Anacreon does not, at least in these surviving lines, single the Scythians out for excessive drinking, but for bad behaviour (cf. Miller 1991:68). For Athenaeus (10.427A-C), who quotes the lines of Anacreon, "Scythian drinking" meant the imbibing of unmixed wine, which could lead to insanity (Hdt. 6.84). Elsewhere (11.499F) he cites the opinion of Hieronymus of Rhodes that to get drunk

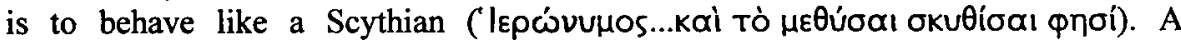
Scythian drinks from a rhyton (indicating unmixed wine) on a red-figure cup (Rhodes 13.386; Lissarrague 1990:90 fig. 74).

Greek authors reveal an ambivalent attitude to their northern neighbours, the Scythians. The locus classicus on the Scythians and their customs is Herodotus 4.1144, an amalgam of anecdote and fact, which Rostovtzeff, for example, accepted more or less at face value, but which modern scholars have increasingly queried (cf. Heinen 1993:17-18, 39-40). The Greek historian's portrait of a strange, barbarous and

behaviour such as excessive drinking (66-69), and argues in favour of its presence as an icon indicating the presence of fashionable oriental goods and thus the status and elitism of the symposiast wearing it (69-71).

9 Page 1975. All the translations are by the author. 
blood-thirsty people, who practised some weird, grisly and cruel customs, and waged war evasively and cunningly, although it is "the earliest study we possess of an uncivilised people" (How \& Wells 1967:302), is a century or two later than the sympotic poetry under discussion, and therefore not strictly relevant. Even if the picture is accurate, there is no evidence that it was present in the minds of the lyric poets or the frequenters of the symposia. In fact, in lyric and other texts the Scythians are portrayed as remote (Theognis 829; Simon. Epigr. $68=$ AP 7.496; Plut. Sept. sap. 5) and nomadic (Pind. fr. 105b Snell-Maehler), but they are also mentioned for Oáyos, a wood used for dyeing (Sappho fr. 210 Lobel-Page; Phot. Lex. 81.12f.) and for a particular kind of shoe (Alcaeus fr. 318 Lobel-Page; Harpocration Lex. 1.277 Dindorf). Their famed archers served in the Athenian army (Arist. Th. 1018, 1026; Lys. 451; but cf. Miller 1991:61-66). The skill and beauty of their metalwork are evident from archaeological finds of their artefacts (cf. Heinen 1993: plates 8-18, 2526, 30; Seltman 1930: plates 78-92, 102-112). The only negative aspects were their rough speech (Plut. Mor. 847F), compared with Greek, of course, and their unbridled behaviour at symposia, induced by the consumption of wine or fermented milk.

The role of wine is a bit surprising. The Scythians were a nomadic people and did not cultivate vineyards or any other crops (Minns 1925:190-192). They drank wine only when it was available (Minns 1925:197). Every year each nomarch prepared a jar of wine from which only those who had killed an enemy could drink: it was a special occasion and the successful warriors could drink two beakers (Hdt. 4.66)-not exactly an intoxicating draught. Instead, one would have thought their drinking-vessels would have fascinated Greek writers: they were made of the skulls of their enemies (Hdt. 4.65; Minns 1925:199); or the potion served at the conclusion of pacts: blood from the negotiators added to the wine (Hdt. 4.70). Their normal drink was kumys, fermented mare's milk, which was as much a sign of barbaric savagery as their alleged wine-drinking (Miller 1991:67-68, 76-77 n. 59, with references).

It is also Anacreon who refers to the behaviour of the Lydians. In $P M G$ fr. 481

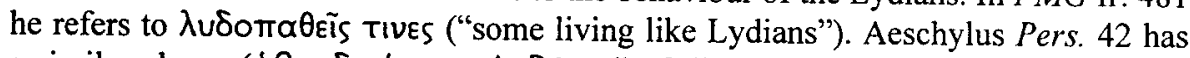
a similar phrase ( $\dot{\alpha} \beta p o \delta ı \alpha i t \omega v . . . \wedge \cup \delta \tilde{\omega} v$, "soft-living Lydians"), and a scholiast on Aeschylus (M, p. 22 Dähnhardt) connects the two phrases and explains that the

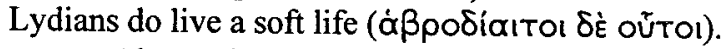

Alcman has a different view of Lydia. In lines which come from a choral ode and therefore not sung at a symposion, he draws a distinction between, on the one hand, a rustic $=$ gauche, uncouth $=$ Thessalian or Erysichaean herdsman and, on the other, someone from Sardis, chief city of Lydia.

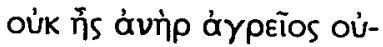

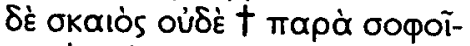

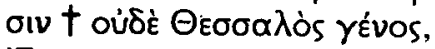

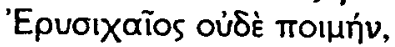

$\dot{\alpha} \lambda \lambda \dot{\alpha} \Sigma \alpha \rho \delta i ́ \omega v$ àrা' ákpãv. 


\author{
He wasn't a rustic man nor \\ uncouth (not even to men \\ of skill) nor Thessalian by race, \\ nor a Erysichaean shepherd, \\ but from elevated Sardis.
}

The phrase "elevated Sardis" is firstly a literal reference to the actual situation of this city, and secondly a figurative evocation of its political and cultural status. Someone from there is clearly considered "superior" to a Thessalian or Erysichaean.

\section{One Greek state vs another}

There are only a few cases where a poet singles out the behaviour of another citystate. Sappho (fr. 106 Lobel-Page) asserts the superiority of the Lesbian poets/ singers, but her poem was not intended for performance at a symposion. On two occasions, Pindar refers to the apparently general and traditional view of the Boeotians as "pigs" or "swine", a reflection on their rusticity and stupidity (cf. also Plato Smp. 182B; Plut. De esu carnium 1.6). In Ol. 6.90 he speaks of the "age-old

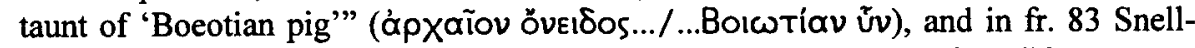
Maehler (quoted and explained by the scholion on $O l .6 .90$ ) he writes: "there was a

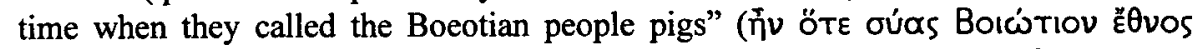
ĚVETIOV). But here too the texts are not sympotic: Olympian ode 6 is, of course, an epinician, while fr. 83, according to the scholiast, comes from a dithyramb (cf. Race 1997:1.114 n.2; 1997:2.314-315).

Two texts of Anacreon's are relevant to our argument. In PMG fr. 399 the Tean poet, addressing an aristocratic symposion at the court of Polycrates of Samos, encourages a girl (presumably a dancer) to remove her chiton in order "to act like a

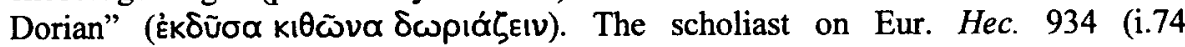

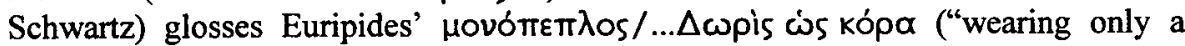
peplos, like a Dorian girl") by quoting this line from Anacreon and explaining that the

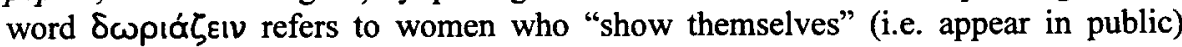

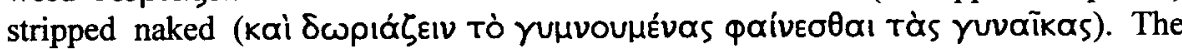
fact that the verb $\delta \omega \rho$ iá $\zeta$ Eıv occurs only here complicates matters. Does it refer to total nudity? Euripides' words refer to wearing the one-piece tunic, without an outer garment. LSJ glosses the verb accordingly: "dress like a Dorian girl, i.e. in a single garment open at the side." The scholiast makes quite a leap from this meaning in Euripides to the one of nakedness in Anacreon. In fact, he bases his definition "stripped naked" on Anacreon's phrase.

Behind the poet's words, of course, is the well-known custom of Dorian (= Spartan) women to exercise semi-naked or naked. Thucydides (1.6.5) states that the Spartans were the first to play games and exercise naked. The practice went back at least to the reforms of Lycurgus in the 8th century, and was customary by the 5th. Plutarch (Comp. Lyc. et Num. 25) quotes the term qaivounpíoas ("thigh-revealing") used by Ibycus ( $P M G$ fr. 339 ) and other poets. He then explains that Numa's reforms 
HENDERSON

were aimed at protecting the femininity and modesty of girls, whereas Lycurgus'

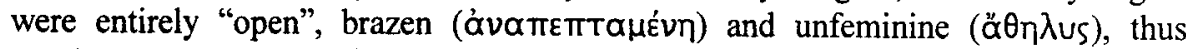

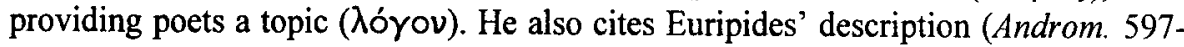

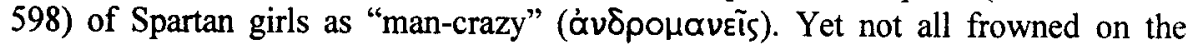
custom: Plato (Rep. 452C-D) defends his view that in his ideal state women should exercise naked as originally in Crete and Sparta.

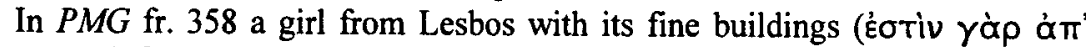

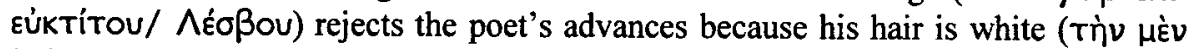

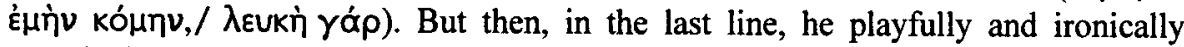

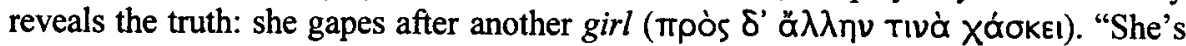
from Lesbos-and we all know what Lesbian girls are like." Anacreon is relying on his audience to know, no doubt from the poetry of Sappho, about the homoerotic relationships in the thiaso i of Lesbos.

\section{One private group vs another}

This phenomenon is reflected exclusively in the poetry of Alcaeus. Among Alcaeus' fragments one finds the more "regular" or positive "uses" of the symposion: enjoyment while one is young, carpe diem (frr. 38a, 346, 347, 352, 401); celebration (frr. 58 and 332); as a cure for cares or sorrows (frr. 50 and 335); and simply to drive away the cold and enjoy pleasant company (fr. 338 Lobel-Page). However, there is a group of fragments where the symposion is clearly the occasion and place for the creation and reinforcement of the "we-they" dichotomy. The "they" in this case are grouped around his bête noir, Pittacus.

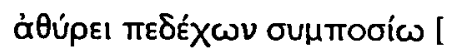

ßáphos,

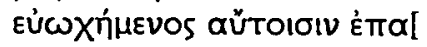

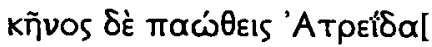

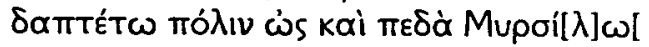

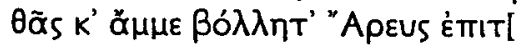

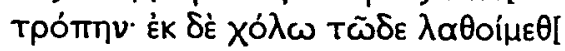

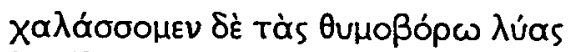

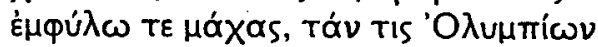

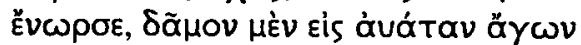

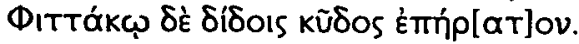

sharing in the banquet [...] the lyre

plays, feasting sumptuously

with vain pretenders, [...] them [

But let him, married to an Atreid, devour the city as he did too with Myrsilus, until Ares wishes to turn us [to arms]. But may we forget this anger [ 
and let us relax from heart-devouring strife

and fighting among ourselves, which an Olympian

has stirred up, leading the people to ruin,

and giving Pittacus glory to enjoy.

Fr. 70 Lobel-Page $^{10}$

The poet sets two types of banquet in opposition: that of the "vain pretenders" to which Pittacus belongs, and that of his own circle. The rival group is labelled as a bunch of social climbers ( $\phi 1 \lambda \omega \dot{\omega} \nu \omega . . . \dot{\alpha} \lambda \varepsilon \mu[\alpha \dot{\alpha} \tau \omega \nu, 4)$ because Pittacus has married a member of the Penthilid-family, who traced their ancestry back to Atreus, father of Agamemnon and Menelaus. " Alcaeus clearly does not take this claim seriously, and attacks Pittacus' family background on more than one occasion (see below on frr. 72 and 129; also, though very broken and uncertain, frr. 75, 106, 119). Here he even extends Pittacus' "flaw" to his entire circle of fellow-banqueters: they are all empty pretenders.

Having cast doubt on the social status of his enemy, Alcaeus now attacks his

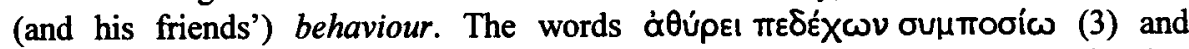

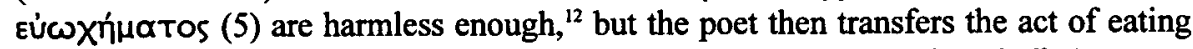
beyond the bounds of the symposion: "let that man devour the city" (Kñvos...

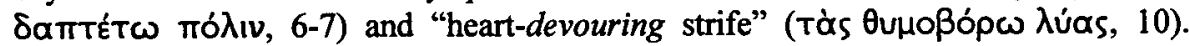

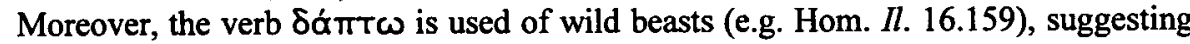
violent and "animal" behaviour on the part of Pittacus. ${ }^{13}$ This all conjours up excessive, dangerous and unacceptable behaviour, which, Alcaeus warns, will lead to

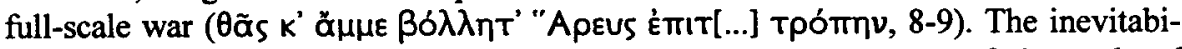
lity of such an outcome is confirmed by the statement that one of the gods of Olympus is responsible for the situation (11), and also by the use of the word áuátav $(=a$ art 12$)$, with its associations of blind folly and inevitable destruction. From this ruin, the poet sarcastically concludes, Pittacus will emerge illustrious.

In contrast, the poet's own symposion is characterised by all that is fine and acceptable: he and his audience should forget the anger, relax and stop the factional fighting (9-11). They are not guilty of the behaviour of "the others". And yet Pittacus received a good "press" in the ancient sources: he was a celebrated military leader of Mytilene, who expelled the tyrant Melanchrus, he was elected and ruled for ten years before retiring voluntarily; he lived to the age of seventy and came to be recognised as one of the Seven Wise Men of the ancient world (Strabo 13.617; Diog. Laert. 1.74, 75, 77; Arist. Pol. 1285a). That Alcaeus' portrait of Pittacus is so different, can only be ascribed to personal animosity, caused by a sense of betrayal, of which a significant part was the realisation that in past symposia Pittacus had not revealed his true self (cf. fr. 69.6-8; Rösler 1980:159-170; 1995:109). Moreover, the aspects or topics targeted by Alcaeus for criticism (social background, physical appearance,

$10 \quad$ Lobel \& Page 1968.

11 The line of descent is: Atreus-Agamemnon-Orestes-Penthilus.

12 There may be a hint of childish or frivolous behaviour in átípet.

13 Pittacus, presumably, is compared to a "fox" in fr. 69.6-8. 
drunkenness and gluttony, animal names, treachery and treason, negative mythological paradigms, sexual innuendo, hoping for and rejoicing in an opponent's death) form part of conventional invective, and are highly suspect as historical facts (cf. Davies 1985:31-39, with further literature).

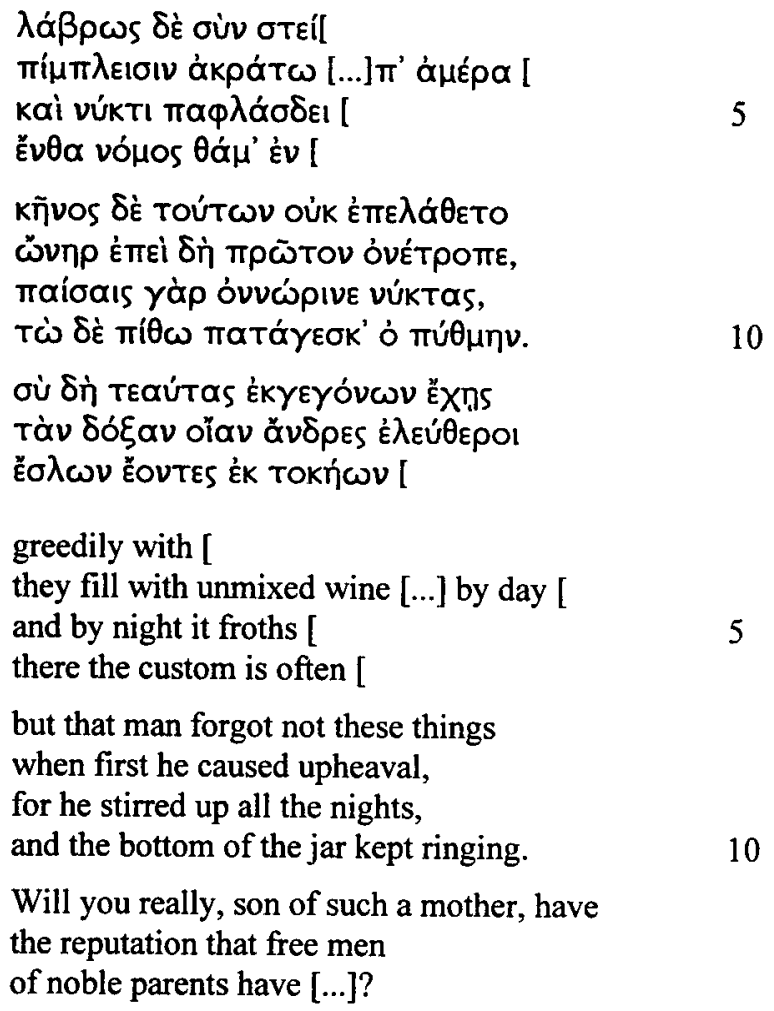

Will you really, son of such a mother, have

the reputation that free men

of noble parents have $[\ldots]$ ?

Fr. 72 Lobel-Page

The poet is clearly using the occasion of the symposion to cast aspersions on the behaviour and family-connections of a rival, probably Pittacus (Page 1965:172-173), whom he addresses directly in the second person in the last three lines. Another person (or Pittacus himself), whom he calls "that man" (kñvos), may be Pittacus' father Hyrrhas (Campbell 1982:277 n.1), or Pittacus' paternal grandfather (Gomme 1957:255-257; Di Benedetto 1955:97-118), or some unknown person who deserted the poet's group for another (Rösler 1980:170-181). What is clear, is the behaviour of the other group during symposia: greedy drinking of undiluted wine, which bubbles and froths day and night, accompanied by some "custom" (vónos) which the damaged text has unfortunately hidden from us (3-6). "That man" was also guilty of causing some form of upheaval, partying all night and playing kottabos (7-10). The last lines place a question mark over the social status of the rival: with such a background he cannot be aristocratic. 
We are informed by Diogenes Laertius (1.74) that Pittacus' father was Thracian, and it is possible that the Thracian reputation for excessive drinking is here being pinned on Pittacus and his family. This means that Alcaeus is using two forms of the "we-they" paradigm: the "our group" vs. "their group", and the "Greek" vs. "non-Greek" one.

In the following fragment, Alcaeus bemoans his lot as an exile and prays for vengeance on the son of Hyrrhas, Pittacus (1-14). This time other aspects of his rival's character and deportment are selected for his attack.

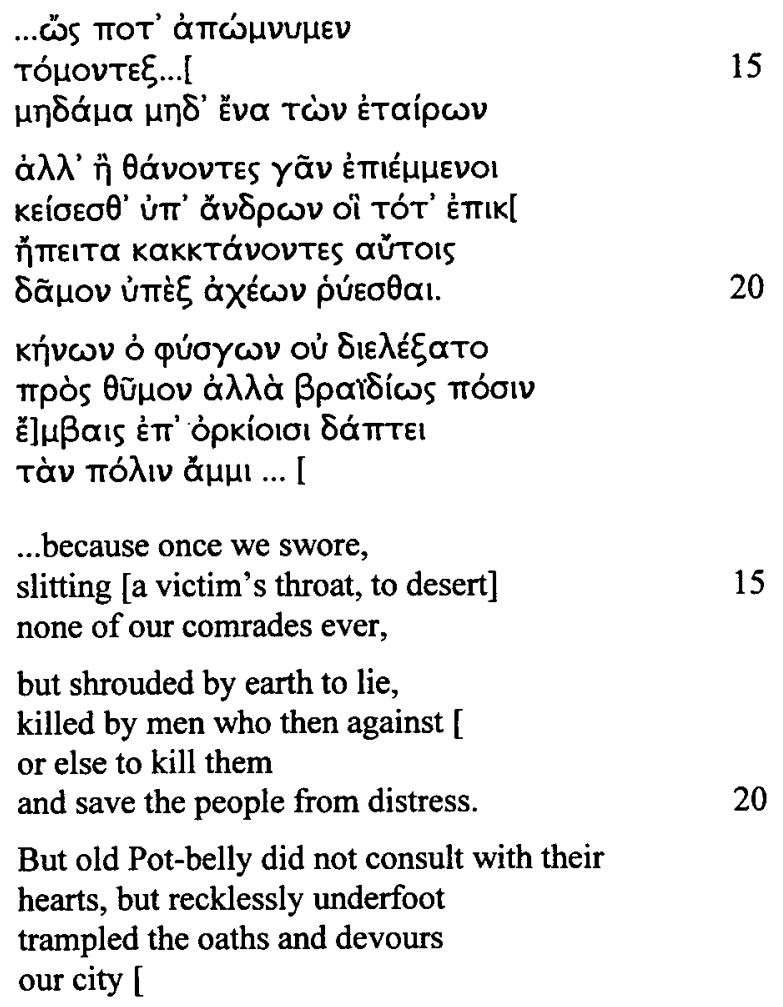

Fr. 129 Lobel-Page

In the first place the poet unleashes a moral indictment: Pittacus is accused of breaking the oath sworn by a group of aristocrats to which the poet also belonged (1420 ). In the poet's view Pittacus is guilty of betrayal. Then he attacks his rival's physical appearance (21) by calling him names, as elsewhere: "coward" (fr. 141), "low-born" (frr. 67, 106, 348), "tyrant" (frr. 75, 306 fr. 9), "Splay-foot", "Chap-foot", "Prancer", "Pot-belly", "Fatso", "Eater-in-the dark" (fr. 429 Lobel-Page). A third accusation is implicit in the image of Pittacus devouring the city (on the use of $\delta a ́$ 'T $\omega$, cf. fr. 70.7 above): he is guilty of illegal and dangerous political activity.

The poem is cast in the form of a prayer addressed to Zeus, Hera and Dionysus as deities of a combined cult on the island of Lesbos (cf. Sappho fr. 17 
Lobel-Page). Yet this is not a hymn written for ritual delivery. There may have been an invocatio in the missing opening, but the pride with which the poet dwells on the Lesbians' creation of this visible and accessible sanctuary for the altars of the three deities (1-8) suggests not so much part of an invocatio as details valued and remembered by the poet on his return from exile on the island. The occasion on which the poem was performed was the symposion (Rösler 1980:191-204).

\section{Conclusion}

Analysis of the poetry sung at symposia confirms that the symposion in early Greek society served as the occasion and place for a group to establish, confirm and communicate its own identity and codes of conduct. Like-minded men gathered to reaffirm their alliances and allegiance. Moreover, the symposion could be used to form, condition and/or reinforce the group's largely negative attitude to and view of other peoples, groups or individuals. This was achieved mainly by means of "essentialising". In the process, acceptable behaviour comes to be associated with "us", non-acceptable behaviour with "them". At the same time, the process served as a form of warning to the group to avoid or resist the behaviour exemplified by "the other group". This evaluation of others could take place despite the generally positive conception "out there". This is best seen in the case of Pittacus, whose reputation beyond Alcaeus' poetry is in stark contrast with the poet's invective. The case of the Scythians is less contrastive: the overall picture is a mixture of positive and negative elements. Anacreon alone of the lyric poets holds up a negative portrait of the Scythians in order to promote a particular code of behaviour, which he, guest-poet at the court of Polycrates of Samos, considers "Greek". Anacreon is also the lyric poet who encourages his audience to make a moral judgement of the behaviour of the women of Sparta and Lesbos.

\section{BIBLIOGRAPHY}

Arias, P E 1962. A History of Greek Vase-Painting. London: Thames and Hudson.

Booth, A 1991. The age for reclining and its attendant perils. In Slater 1991a:105120.

Campbell, D A 1982. Greek Lyric. Vol. I: Sappho and Alcaeus. Loeb Classical Library. Cambridge, Mass./ London: Harvard University Press.

Davies, M 1985. Conventional topics of invective in Alcaeus. Prometheus 11:31-39.

Di Benedetto, V 1955. Pittaco e Alceo. PP 10:97-118.

Gomme, A W 1957. Interpretations of some poems of Alkaios and Sappho. JHS 77:255-266.

Heinen, H 1993 (trans. \& ed.). M. Rostowzew, Skythien und der Bosporus, Band II. Wiederentdeckte Kapitel und Verwandtes. Historia Einzelschriften 83. Stuttgart: Franz Steiner Verlag.

Henderson, W J 1997. Elegie en sumposion. Akroterion 42.1:4-22. 
Henderson, W J 2000 (forthcoming). Aspects of the ancient Greek symposion. Akroterion 45.

How, W W \& Wells, J 1967 [1912]. A Commentary on Herodotus. Oxford: Clarendon Press.

Lissarrague, F 1990. The Aesthetics of the Greek Banquet. Images of Wine and Ritual. (Un flot d'images, Paris 1987). Transl. by Szegedy-Maszak, A. Princeton: Princeton University Press.

Lobel, E \& Page, D L 1968 [1955]. Poetarum Lesbiorum Fragmenta. Oxford: Clarendon Press.

Maas, M \& Snyder, J M 1989. Stringed Instruments of Ancient Greece. New Haven/ London: Yale University Press.

Miller, M 1991. Foreigners at the Greek symposium? In Slater 1991a:59-81.

Minns, E H 1925. The Scythians and Northern Nomads. In Bury, J B, Cook, S A \& Adcock, F E (eds.), The Cambridge Ancient History, 3:187-205. Cambridge: University Press.

Murray, O (ed.) 1990. Sympotica. A Symposium on the Symposion. Oxford: University Press.

Murray, O 1991. War and the symposium. In Slater 1991a:83-103.

Murray, O \& Tecusan, M (eds.) 1995. In Vino Veritas. London: British School at Rome.

Page, D L 1965 [1955]. Sappho and Alcaeus. Oxford: Clarendon Press.

Page, D L 1975 [1962]. Poetae Melici Graeci. Oxford: Clarendon Press.

Race, W H 1997. Pindar. Vol. I: Olympian Odes, Pythian Odes. Vol. II: Nemean Odes, Isthmian Odes, Fragments. Loeb Classical Library. Cambridge, Mass./ London: Harvard University Press.

Rösler, W 1980. Dichter und Gruppe. Eine Untersuchung zu den Bedingungen und zur historischen Funktion früher griechischer Lyrik am Beispiel Alkaios. Munich: Fink.

Rösler, W 1995. Wine and truth in the Greek symposion. In Murray \& Tecusan 1995:106-112.

Seltman, C T (ed.) 1930. The Cambridge Ancient History. Plates, Vol. III. Cambridge: University Press.

Slater, W J (ed.) 1991a. Dining in a Classical Context. Ann Arbor: University of Michigan Press.

Slater, W J 1991b. Introduction. In Slater 1991a:1-5.

Tecuşan, M 1990. Logos sympotikos: patterns of the irrational in philosophical drinking: Plato outside the Symposion. In Murray 1990:238-260.

Whitaker, R 1997. The Classics in South African society-past, present and future. AClass 40:5-14. 